\title{
How bank capital structure decision-making change in recessions: Covid-19 evidence from Pakistan
}

How covid affected capital structure of banks

Khalil Ullah Mohammad

Bahria University, Islamabad, Pakistan
Received 19 April 2021 Revised 9 June 2021 26 July 2021

Accepted 25 October 2021

\begin{abstract}
Purpose - This study contributes to existing literature by investigating bank capital structure dynamics during the Covid-19 pandemic. The role of contemporary bank-specific determinants of capital structure during this period is analyzed.

Design/methodology/approach - An independent $t$-test is carried out to check the response of bank leverage to the crisis. Using fixed effect estimation and difference general method of moments (GMM), the impact of the shock is examined. An unbalanced quarterly data set from $2016 \mathrm{q} 1$ to $2020 \mathrm{q} 3$ of all commercial banks in Pakistan is used.

Findings - The study finds that due to procyclicality of capital, during the Covid-19 crisis, the banks preempted a fall in capital and improved their capital positions. The role of bank specific variables in determining capital structure like profitability, size and competition weakened during this period. Evidence suggests that policy rate intervention by the central bank was a significant factor in capital structure decisions during the Covid-19 period. The study finds that macroeconomic shocks have significant impact on capital structure decision-making of banks which goes beyond the bank-specific factors.

Originality/value - It finds evidence of a moderating role of monetary policy in capital structure decisionmaking which has not been previously highlighted in literature. Monetary policy is found to become an important factor deciding the capital structure of banks during the Covid-19 first 3 quarters. This study also explores the impact of Covid-19 on the bank-specific determinants of capital structure of banks.
\end{abstract}

Keywords Financial crisis, Capital structure, Leverage, Covid-19, Central banking

Paper type Research paper

\section{Introduction}

The 2008 financial meltdown taught us that undercapitalization makes banks vulnerable during recessions. High-quality bank capital is crucial for continuous lending by banks and reduces their probability of default, especially during and after crisis periods (Berger and Bouwman, 2013; Carlson et al., 2013; Doku et al., 2019).

Post-2008, regulatory reforms were taken to ensure capital adequacy in banks, and improvements in regulatory oversight and revisions of capital standards took place. A permanent change in capital structures of banks took place and banks improved their capital positions (Hussien et al., 2019). Leverages maintained by banks exhibit variability across banks and countries. It is found that banks maintain capital positions above the regulatory requirements as predicted by the bank buffer theory. Peura and Keppo (2006) attribute this cross-country variation to return volatility and market imperfections.

\section{JEL Classification - G10, G21, G32}

(C) Khalil Ullah Mohammad. Published in Asian Journal of Economics and Banking. Published by Emerald Publishing Limited. This article is published under the Creative Commons Attribution (CC BY 4.0) licence. Anyone may reproduce, distribute, translate and create derivative works of this article (for both commercial and non-commercial purposes), subject to full attribution to the original publication and authors. The full terms of this licence may be seen at http://creativecommons.org/licences/by/4.0/ legalcode.

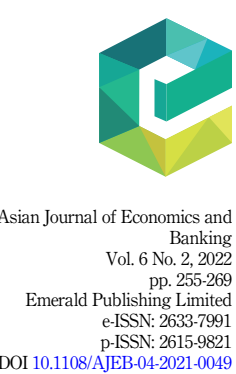


AJEB

6,2
Capital structure decision-making by banks is still not completely understood, and regulatory requirements might not be the only determinant. Contemporary empirical evidence suggests that it may be determined by a range of bank-specific factors (Ghosh and Chatterjee, 2018; Gropp and Heider, 2010; Mohammad and Nishiyama, 2019). Understanding capital structure choice of banks is important because there is a trade-off between liquidity creation and default risk minimization, and there is an indirect implication of high capitalization on monetary policy transmission through the bank capital channel.

Contrary to bank-specific factors, there is evidence that leverage was affected by the 2008 crisis (Ghosh and Chatterjee, 2018; Mohammad et al., 2021). After a decade, SARs-Covid-19 came as a similar shock to the global financial system. Li et al. (2020) suggest that bank capital buffers were more robust before the crisis unlike 2008 and therefore were not met by any financial constraints when countries experienced liquidity shocks. How did banks respond to the crisis in terms of their liability-side balance sheet? Were the traditional determinants of capital structure decisions of banks relevant during recessions? These are questions that are still not fully addressed in literature.

There is a dearth of empirical evidence on how capital structure decision-making changes during recessions. This study tests if bank-specific factors explain the capital structure decisions of banks. Using quarterly data of commercial banks from Pakistan, a dummy variable multivariate fixed effect estimation model, the study analyzes how banks responded in reference to their capital structure choice. Pakistan presents a special case because, unlike the rest of Asia, closure of institutions was done for a limited time where the entire country went into lockdown and banks reported record profits during the first two quarters of 2020.

\section{Literature}

Bank capital structure refers to how banks finance their balance sheets, and its determinants are still not fully understood and have gained a lot of attention in contemporary empirical literature. However, capital structure decision-making by nonfinancial firms has been extensively covered in corporate finance literature. Of the plethora of capital structure theories, the trade-off and pecking order theories have been the most empirically tested with evidence in favor of both. Some of the significant studies are (Benito, 2003; Tran et al., 2020; Hoque and Kashefi-Pour, 2015; Rajan and Zingales, 1995; Sharpe, 1995).

Banking literature has mainly attributed capital structure to regulatory requirements or bank-specific factors. Some of the bank-specific factors identified in literature include size, tangibility, liquidity, profitability, tax rate, risk and growth. Theories predict contradictory effects of these factors on bank capital structure. By testing traditional theories, the role of information asymmetry and capital regulation has been stressed (Al-Hunnayan, 2020; Benito, 2003; Dowd, 1999; Johnson, 1998; Miles, 1995; Qayyum and Noreen, 2019). Miles (1995) has been seminal in this regard, attributing the depositor's inability to access banks (information asymmetry) as a factor that incentivizes risk-taking and low capital ratios in banks. Alkhazaleh and Almsafir (2015) find evidence in support of the argument.

Gertler and Kiyotaki (2010), however, propose that higher asymmetry of information between the depositor and the bank leads to lower deposits. The depositors would prefer investing in other alternatives rather than keeping their money in the bank. This would result in a shrinkage in the deposit ratio, therefore contradicting Miles (1995). Dowd (1999) advocating free banking reasons, the argument that depositors cannot assess capital being maintained by banks, is far-fetched and therefore there is no need for capital regulation.

Theories have also suggested that capital regulation may be the factor that impacts the capital structure decision. Orgler and Taggart (1983) suggest that bank size, taxes, default risk, technology and government regulation play a role in deciding capital structure. Flannery (1994) and Pennacchi (1987) also suggest similar indicators and highlight capital 
requirement as an important determinant. Ghosh and Chatterjee (2018) find contradicting evidence on the role of capital regulation in determining bank capital structure.

More contemporary literature focuses on individual-specific characteristics as determinants of individual banks' financing decisions (Bitar et al., 2019; Bukair, 2019; Ghosh and Chatterjee, 2018; Gropp and Heider, 2010; Mohammad and Nishiyama, 2019). Factors like liquidity requirements and debt market conditions have also been attributed to capital structure choice (Alraheb et al., 2019).

Bank capital structure decisions have implications for bank intermediation and its stability. Capital helps in reducing default risk but negatively impacts liquidity creation (Diamond and Rajan, 2002). The attributes lack of sufficient regulatory requirements and deposit insurance for the fluctuations in bank capital ratios. Bernanke and Gertler (1985) show that capital, asset risk and monitoring costs have an impact on bank's intermediation. Banks have the incentive to keep low capital, but higher capital requirements can also adversely impact the lending and lead toward risky behavior (Calem and Rob, 1999; Jackson et al., 1999). Hellmann et al. (2000) find that capital requirements may reduce this behavior. Instead, it affects the bank franchise value, thus encouraging gambling. The model by Sundaresan and Wang (2014) predicts that banks prefer to keep high leverages, but regulations and deposit insurance impact leverages negatively. Other factors that impact the liability-side balance sheet are how subordinated debt and deposits respond to bank risk profile, the tax regime and operating costs. Mohammad and Nishiyama (2019) find empirical evidence to support this hypothesis in the case.

Kalemli-Ozcan et al. (2012) also find that bank leverage fell during the subprime crisis but was lower in emerging countries. Goodhart (2008) also suggest that capital exhibits procyclical behavior. Han and Melecky (2014), however, suggest that deposits also grew during the 2008 crisis, which makes understanding the overall effect on capital structure ambiguous. Other studies that find evidence of increase in deposits are (Goedde-Menke et al., 2014).

Studies on bank capital response to Covid-19 crisis are limited as the economies have till recently been experiencing the crisis. However, those studies that have conducted have found a growth in zombie lending and an increase in deposits in banks. During Covid-19, zombie lending was done by overcapitalized banks, while better capitalized banks decreased lending (Dursun-de Neef and Schandlbauer, 2020).

Schularick et al. (2020) suggest that better capitalization has improved economic recovery in times of crisis. Dursun-de Neef and Schandlbauer (2020) find that during the crisis, capital positions of the US banks decreased and insured deposits increased. This is contrary to the experience of banks during the 2008 financial crisis.

Previous literature indicates a significant impact on the capital structure of banks during an economic downturn. There are mixed findings on the direction of the response. Based on the studies, the following null hypothesis are tested.

H1. Bank leverage is unaffected by the Covid crisis.

H2. Primary capital structure determinants are unaffected by the Covid crisis.

It is hypothesized that during the crisis period, the capital structure of banks would be unaffected. During the crisis, it is hypothesized that primary determinants of capital structure should also be unaffected. This study adds to existing knowledge on the impact of recessions on capital structure by investigating structural changes in balance sheets due to the Covid crisis.

\section{Methodology}

Quarterly data from 2016 to 2020 of all commercial Islamic and conventional banks operating in Pakistan are used to carry out a dummy variable pre-post-analysis of how leverages of 
AJEB

6,2

banks changed during the crisis. An independent $t$-test is carried out to test for any significant difference between the means pre-crisis and during the crisis. The fixed effect estimation is the used to test for the impact of the crisis on the leverage of banks in Pakistan.

$$
\begin{aligned}
\text { Leverage }_{i t}= & \alpha_{i t}+\beta_{1} \text { Crisis }_{t}+\beta_{2} \text { Liquidity Ratio }_{i t}+\beta_{3} \log (\text { total Assets })_{i t}+\beta_{4} \text { Tax Ratio }_{i t} \\
& +\beta_{5} \text { Overhead }_{i t}+\beta_{6} \text { Profitability }_{i t}+\beta_{7} \text { Loan Ratio }_{i t}+\beta_{8} \text { Policy Rate }_{t} \\
& +\beta_{9} \log \left(\text { OMO Injections }_{t}+\beta_{10} \mathrm{HHI}_{t}+\beta_{10} \text { IndustryLeverage }_{t}+\varepsilon_{i t}\right.
\end{aligned}
$$

In the model $t$ depicts the quarterly time subscript and $i$ the bank. The model uses (1-K/A) as the dependent variable depicting leverage where $\mathrm{K}$ is the total capital and $\mathrm{A}$ is the total assets (Frank and Goyal, 2004; Gropp and Heider, 2010; Mohammad and Nishiyama, 2019). The ratio is well defined and allows for consistent comparison across studies. Liquidity ratio is the ratio of current assets as a percentage of total assets (Lipson and Mortal, 2009). de Jong et al. (2008) claim that companies with a higher liquidity ratio will have a high debt to equity ratio because of the need to repay interest payments. The bank size is captured by the log of total assets (Bukair, 2019; Rajan and Zingales, 1995). According to Pecking order theory, as a firm grows and generates more profit, it prefers internal sources of finances rather than taking debts. Trade-off theory assumes that larger firms will have higher debt ratios because they can enjoy getting loans on very reasonable amounts, positively impacting the leverage ratio. Tax ratio is total tax as a ratio of total assets. Modigliani and Miller (1958) suggest that the debt ratio increases as the tax rate increases. To create a reduction in taxable income, a firm needs to use more debt along with a decent marginal tax rate. Open market operation (OMO) injections is the log of total open market injections done in each quarter. Policy rate is the policy rate as of the end date of each quarter. The theory on bank capital channel of monetary policy suggests that monetary policy transmission is effected by bank capital structure. Monetary policy affects bank lending through an indirect effect on bank capital. The Herfindahl-Hirschman Index (HHI) proxies the concentrations in the banking sector and is calculated as market share of a bank as a portion of the total industry (Gropp and Heider, 2010). Overhead is the ratio of non-interest expenses as ratio of total assets (Mohammad et al., 2021). Overhead and bank concentration are used as control variables.

The model uses the crisis 0-1 dummy to represent the period of the Covid crisis and takes quarters $1-3$ of 2020 as the period during which the economy was affected by the crisis. Ghosh and Chatterjee (2018) use a crisis dummy to investigate this impact during the 2008 financial crisis. Bhagat et al. (2015) use a similar method to investigate the effect of the 2008 financial crisis on risk-taking behavior and bank size. Gropp and Heider (2010) use interaction dummy to investigate the role of capital regulation on bank leverage.

Quarterly data of banks is taken from DataStream and individual bank balance sheets. Historical data on monetary policy (OMO injections/policy rate) have been taken from the State Bank of Pakistan's official website. The data are tested for multicollinearity by analyzing the correlation matrix and the VIF scores. Outliers are removed, and the estimation is done using robust standard errors to resolve problems of heteroskedasticity. As a robustness check, the model is converted to a dynamic panel by including a lag term. Table 1 lists the variables and the descriptive statistics.

\section{Result}

Table 2 reports the results of the independent $t$-tests. There is significant evidence to reject $\mathrm{H} 1$. We find that there is a significant difference in bank leverages maintained before and 


\begin{tabular}{|c|c|c|c|c|c|c|c|}
\hline & Variable & Obs & Mean & Std. Dev. & Min & Max & \\
\hline 1 & $1-\mathrm{K} / \mathrm{A}$ & 366 & 0.923 & 0.049 & 0.095 & 0.966 & structure of \\
\hline 2 & Crisis & 366 & 0.219 & 0.414 & 0 & 1 & \\
\hline 3 & Liquidity & 366 & 0.103 & 0.06 & 0.033 & 0.33 & Dant \\
\hline 4 & Log(assets) & 366 & 27.1 & 0.942 & 25.091 & 30.063 & \\
\hline 5 & Tax ratio & 366 & 0.004 & 0.004 & 0 & 0.04 & \\
\hline 6 & Overhead & 364 & 0.012 & 0.008 & 0.001 & 0.069 & 259 \\
\hline 7 & Profitability & 366 & 0.01 & 0.01 & 0 & 0.088 & \\
\hline 8 & Loan to total assets & 366 & 0.32 & 0.141 & 0.001 & 0.609 & \\
\hline 9 & Policy rate & 345 & 0.081 & 0.029 & 0.058 & 0.138 & \\
\hline 10 & $\log$ (OMO injections) & 345 & 16.167 & 1.301 & 11.17 & 16.85 & \\
\hline 11 & HHI & 366 & 0.093 & 0.02 & 0.081 & 0.17 & Descriptive statis \\
\hline
\end{tabular}

\begin{tabular}{|c|c|c|c|c|c|c|c|}
\hline \multirow{2}{*}{$\frac{\text { Group }}{0}$} & \multirow{2}{*}{$\frac{\text { Obs }}{286}$} & \multirow{2}{*}{$\begin{array}{c}\text { Mean } \\
0.9245723\end{array}$} & \multirow{2}{*}{$\begin{array}{r}\text { Std. Err. } \\
0.001439\end{array}$} & \multirow{2}{*}{$\frac{\text { Std. Dev }}{0.0243358}$} & \multicolumn{2}{|c|}{ [95\% Conf. Interval] } & \\
\hline & & & & & 0.9217398 & 0.9274047 & \\
\hline 1 & 80 & 0.9158371 & 0.0106541 & 0.0952933 & 0.8946306 & 0.9370436 & \\
\hline \multirow{3}{*}{$\begin{array}{l}\text { Combined } \\
\text { diff } \\
\text { Ha: diff }<0 \\
\operatorname{Pr}(T<t)=\end{array}$} & 336 & 0.9226629 & 0.0025825 & 0.0494058 & 0.9175845 & 0.9277414 & \\
\hline & \multirow{2}{*}{0.0087352} & 0.0062405 & & & -0.0035368 & 0.0210071 & Table 2. \\
\hline & & \multicolumn{3}{|c|}{$\begin{array}{c}\text { Ha: diff } !=0 \\
\operatorname{Pr}(|T|>|t|)=0.1624\end{array}$} & \multicolumn{2}{|c|}{$\operatorname{Pr}(T>t)=0.0812$} & $\begin{array}{l}\text { Difference } t \text {-test of } \\
\text { leverage by crisis }\end{array}$ \\
\hline
\end{tabular}

during the crisis. The means show that during the crisis period, leverage of banks in Pakistan decreased and capital positions maintained by banks strengthened by approximately $1 \%$.

Table 3 reports the results of the unbalanced fixed effect estimation after controlling for the typical determinants of capital structure identified in literature. The model fit is $32 \%$ which is lower compared to the book value model estimated by Gropp and Heider (2010) for the US and UK banks. Model 1 results show that bank size, tax ratio, profitability, industry average leverage and bank concentrations are significant factors in the capital structure decision-making of Pakistani banks.

The bank assets are found to positively impact leverages. This is consistent with previous research, which shows that larger banks tend to keep lower capital positions compared to smaller banks (Gropp and Heider, 2010; Mohammad and Nishiyama, 2019; Rajan and Zingales, 1995). Antoniou et al. (2008) find leverage ratio for nonfinancial firms is positively affected by but declines with an increase in firm profitability. Bank profitability is found to affect the leverage of banks negatively which is consistent with previous findings. Schepens (2016) find a significant role of tax on capital structures of banks, and reduction in tax advantage of debt results in increase capital ratios. We also find the tax ratio to negatively impact leverage of the banks. The risk absorption hypothesis argues that increase in liquidity is directly related with capital. Liquidity does not have any significant impact on the capital structure. However, the sign is negative which is consistent with the financial fragilitycrowding out hypothesis (Gorton and Winton, 2017; Li et al., 2020). Open market operations by the central bank are hypothesized to affect the leverage of banks. Lending by banks increases as announcement of central bank purchases is made (Grosse-Rueschkamp et al., 2019). Our estimates, however, do not show any impact of open market operations on the banks' leverage.

We find that policy rate is statistically insignificant. However, using general method of moments (GMM), the effect becomes significant at 10\% level. Controlling for the crisis period in model 2 improves the model fit by 4\%. Li et al. (2020) suggested that banks were better 
\begin{tabular}{l} 
AJEB \\
6,2 \\
$\mathbf{2 6 0}$ \\
\hline
\end{tabular}

Table 3.

Fixed effect estimation results using $(1-\mathrm{K} / \mathrm{A})$ as leverage

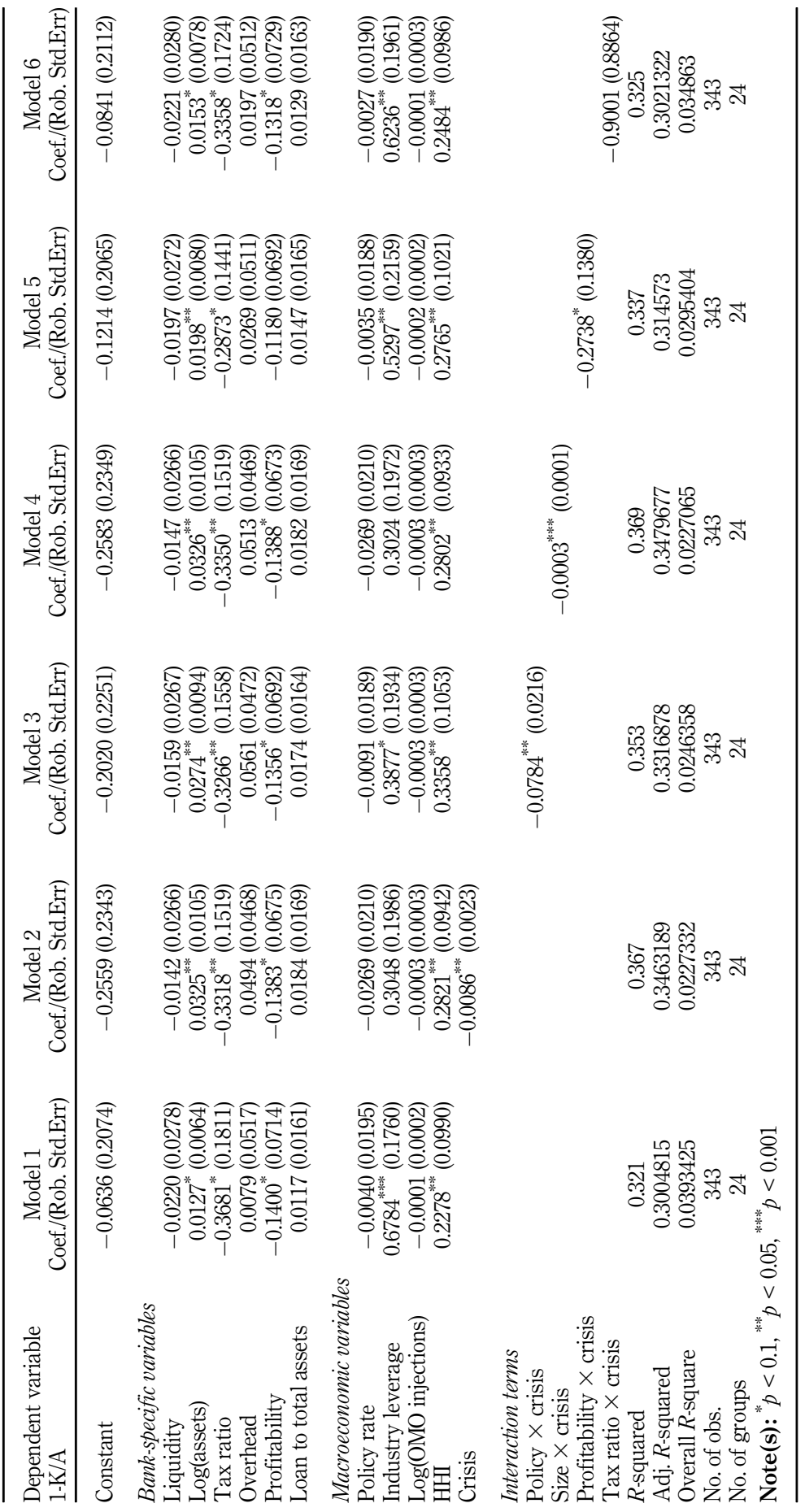


capitalized before the Covid-19 crisis, but evidence indicates that banks improved their capitalization further to ensure that they are not faced by any financing constraints. This is additional evidence favoring the rejection of H1. Empirical evidence suggest that small nonfinancial firms deleverage during recessions (D'Amato, 2020; Demirgüç-Kunt et al., 2020). Model 2 results indicate that the crisis dummy is negative and significant at $1 \%$, suggesting that during the period of the crisis, banks have responded by increasing the capital positions. Košak et al. (2015) suggest that during the 2008 crisis, banks' tier 2 capital strengthens. This finding is consistent for our findings during the Covid-19 pandemic.

By interacting the crisis dummy with the determinants of capital structure, models 3 to 6 test whether these determinants still remained important in capital structure decisionmaking during the recession period. The interbank lending rate (policy rate) is not found to have an impact on the banks' leverage. However, in model 3, a significant impact is found when we investigate the effect of the policy rate on bank leverage during the Covid crisis, using an interaction term. Facing a foreign currency reserve crisis in 2017, the central bank had increased interest to exceptionally high levels to attract hot money. During the Covid crisis, the rate was decreased significantly to improve liquidity in the market. Evidence suggests that it has a significant impact on the capital structure.

Bank size is found to positively affect bank leverage. Larger banks keep lower capital positions and can attract higher deposits. Model 4 shows that during the crisis, the role of size in determining capital structure reduced; however, magnitude is very small compared to profitability and tax. Model 5 shows that the role of profitability as a determinant of bank capital structure became more important during the crisis. The role of taxation in determining the capital structure was not found to be significantly different from before the crisis. Evidence suggests that $\mathrm{H} 1$ is rejected, and primary determinants of capital structure are affected. Profitability and policy rate become more important in determining capital structures of banks during crisis.

\subsection{Robustness}

To confirm robustness of results difference, GMM is applied on the data to cater to any endogeneity problems. The use of instruments reduces the number of observations, but the result is consistent with our findings.

Similar to the earlier findings, policy rate, bank size, profitability and tax are all found to have a significant impact on bank leverage during the crisis period. The hypothesis that primary capital structure determinants are unaffected during recession is rejected, and we find that magnitude of policy rate and profitability during crisis increases. However, unlike the fixed estimation results, policy rate is found to be significant at $10 \%$ under the GMM estimation (see Table 4).

Consistent with the fixed effect estimation finding, model GMM 1 shows that during crisis the leverage ratio decreases. Models GMM 2-5 test the impact of crisis policy rate, size, profitability and tax ratio as capital structure determinants. Evidence suggests that policy rate and profitability become more important determinants during crisis periods. The magnitude of size and tax ratio falls after using interaction terms, suggesting a decrease in importance of these factors in times of crisis.

Sari et al. (2018) use debt to equity ratio to measure capital structure and find that in Indonesia, liquidity, institutional ownership and bank age determine leverage, and profitability risk and dividend do not. Table 5 reports the findings of using debt to equity ratio as the proxy of bank leverage. Using the second proxy of leverage, the size still has a significant positive impact on bank leverage decisions, and during the crisis its importance in terms of size reduces. Loans are also found to significantly impact the bank's debt to equity measure of leverage, which was not the case in the original model. Overall debt to equity as a 
AJEB
6,2

262

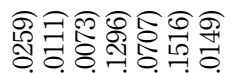

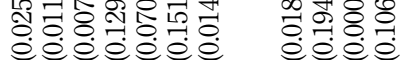

*

廿े

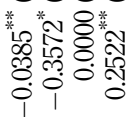

तิ ๙ิণ 륭ㄹㅇ

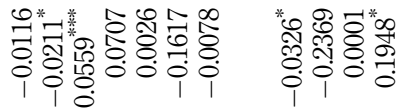

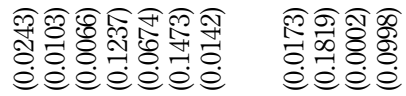

*

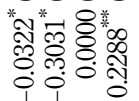

롱

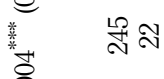

।

ஓ̨̊

苗 ลั

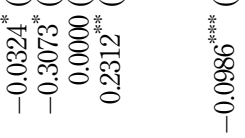

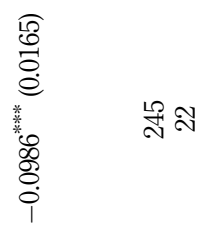

녁 굥

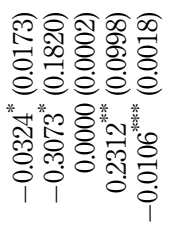

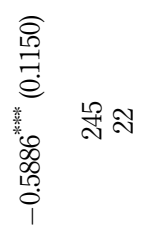

ㄲํㅇํํㅇํำำ

웡ㅇㅇㅇㅇㅇㅇㅇㅇㅇㅇㅇ

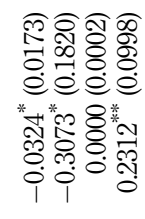

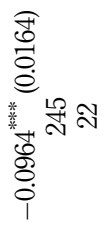

ลิ

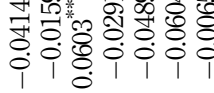

สํํㅇํำํํำ

¿.

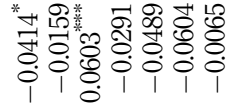

$\mid$

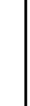

Table 4.

GMM estimation of all the five models used in Table 3 


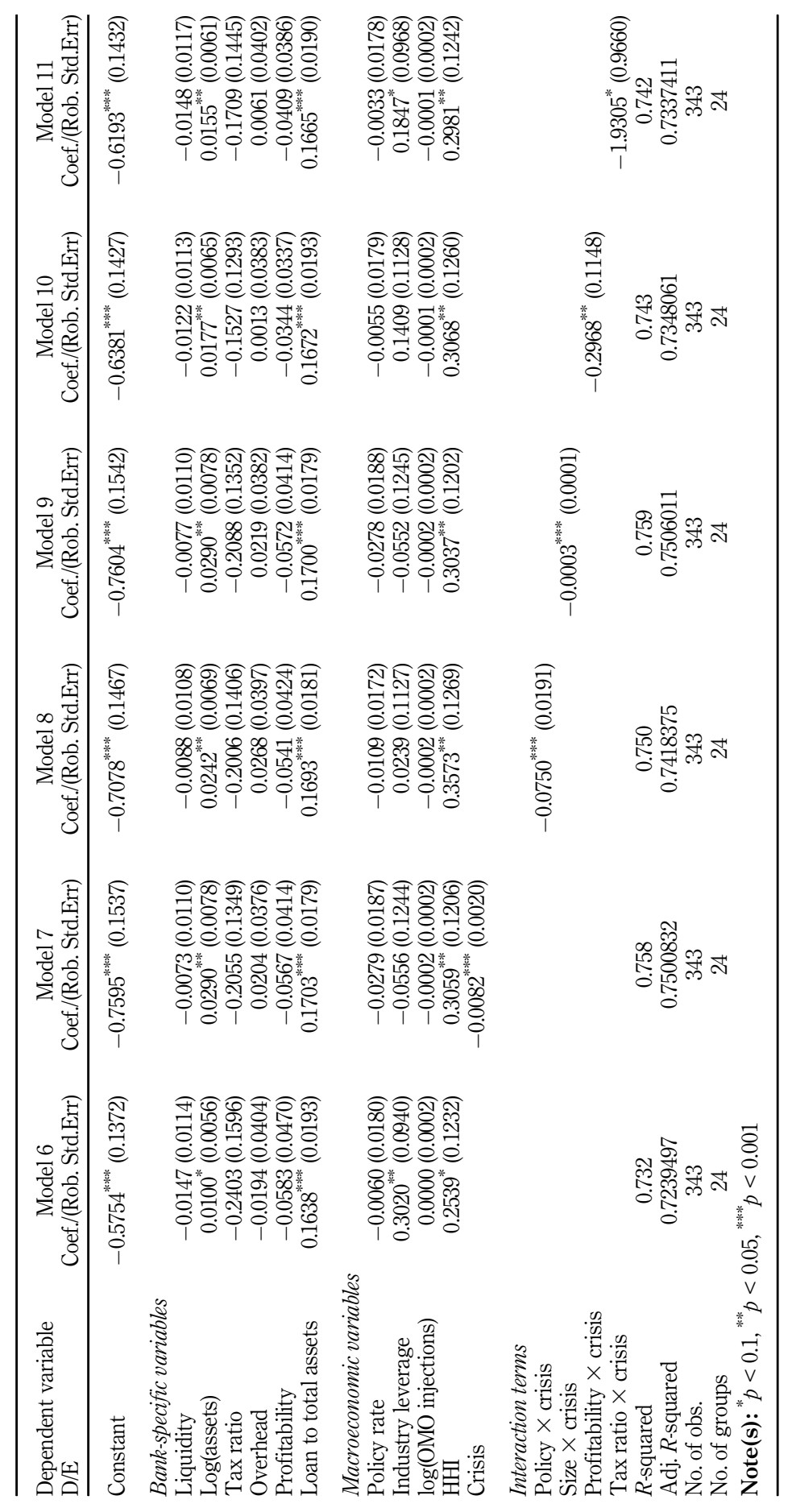

How covid affected capital structure of banks

263

Table 5.

Fixed effect estimation results using (debt to equity ratio) as leverage 
AJEB

6,2

\section{4}

measure of bank leverage is also found to be negatively impacted during the Covid-19 period. Increase capital position by banks seems to be the logical reason for this effect. However, compared to (1-K/A), profitability and tax ratio are no longer significant, although the signs of the estimation result are consistent. Other primary determinants of liquidity, tax ratio and profitability are found to be insignificant, and only the interaction terms are found to be significant. Loan ratio becomes a significant determinant in case of debt to equity ratio, which is contrary to the original findings. This may be due to difference in what portion of the bank balance sheet is being depicted by the two dependent variables used.

The results suggest that capital positions strengthened during the first three quarters of the pandemic. This finding is consistent with bank behavior during the 2008 financial crisis. We also find that during the crisis, bank-specific factors lost their explanatory power in terms of magnitude to determine capital structure, and macroeconomic policy rate played a more important role during the crisis period.

\section{Conclusion}

The objective of the study was to identify the impact of Covid-19 on the bank capital structure and its determinants using Pakistani banks as a test case. The importance of primary capital structure determinants during the Covid-19 crisis is also tested. Due to the procyclicality of capital, contrary to Li et al. (2020), we find that banks in a forward-looking behavior improved their capital positions to preempt the effects of crisis similar to the 2008 financial crisis (Mohammad et al., 2021).

This study contributes to the existing literature on capital structure of banks by showing that the role of bank-specific variables in determining capital structure like profitability, size and competition weakened during the Covid-19 period. Unlike bank-specific variables (Gropp and Heider, 2010), we also find that policy rate intervention by the central bank became a significant factor in capital structure decisions during the Covid-19 period. The study finds that macroeconomic shocks have significant impact on capital structure decision-making of banks, which goes beyond the bank-specific factors.

Bank capital is crucial for continuous lending by banks and reduces their probability of default, especially during and after crisis periods (Berger and Bouwman, 2013; Carlson et al., 2013; Doku et al., 2019). Findings suggest that the central bank's policy rate becomes an important determinant of the capital structures of banks and their role is enhanced during recessionary periods. Central banks should therefore consider the impact of policy rate on capital structure of banks and their stability when responding to economic shocks. Similarly, the study finds that banks with higher profitability will be able to ensure capital adequacy during crisis periods.

\section{References}

Al-Hunnayan, S.H. (2020), "The capital structure decisions of Islamic banks in the GCC”, Journal of Islamic Accounting and Business Research, Vol. 11 No. 3, pp. 745-764, doi: 10.1108/JIABR-022017-0026.

Alkhazaleh, A.M. and Almsafir, M.K. (2015), "Does asymmetry of information drive banks' capital structure? Empirical evidence from Jordan”, International Journal of Economics and Finance, Vol. 7 No. 3, doi: 10.5539/ijef.v7n3p86.

Alraheb, T.H., Nicolas, C. and Tarazi, A. (2019), "Institutional environment and bank capital ratios", Journal of Financial Stability, Vol. 43, pp. 1-24, doi: 10.1016/j.jfs.2019.05.016.

Antoniou, A., Guney, Y. and Paudyal, K. (2008), "The determinants of capital structure: capital market-oriented versus bank-oriented institutions", Journal of Financial and Quantitative Analysis, Vol. 43 No. 1, pp. 59-92, doi: 10.1017/s0022109000002751. 
Benito, A. (2003), "The capital structure decisions of firms: is there a pecking order?", in Documentos de trabajo del Banco de España.

Berger, A.N. and Bouwman, C.H.S. (2013), "How does capital affect bank performance during financial crisesa”, Journal of Financial Economics, Vol. 109 No. 1, pp. 146-176, doi: 10.1016/j.jfineco.2013. 02.008 .

Bernanke, B. and Gertler, M. (1985), Banking in General Equilibrium, Working Paper No. 1647, National Bureau of Economic Research.

Bhagat, S., Bolton, B. and Lu, J. (2015), "Size, leverage, and risk-taking of financial institutions",

How covid affected capital structure of banks Journal of Banking and Finance, Vol. 59, pp. 520-537, doi: 10.1016/j.jbankfin.2015.06.018.

Bitar, M., Pukthuanthong, K. and Walker, T. (2019), "Efficiency in Islamic vs. conventional banking: the role of capital and liquidity", Global Finance Journal, Vol. 46, 100487, doi: 10.1016/j.gfj.2019. 100487.

Bukair, A.A.A. (2019), "Factors influencing Islamic banks' capital structure in developing economies", Journal of Islamic Accounting and Business Research, Vol. 10 No. 1, pp. 2-20, doi: 10.1108/JIABR02-2014-0008.

Calem, P. and Rob, R. (1999), “The impact of capital-based regulation on bank risk-taking”, Journal of Financial Intermediation, Vol. 8 No. 4, pp. 317-352, doi: 10.1006/jfin.1999.0276.

Carlson, M., Shan, H. and Warusawitharana, M. (2013), "Capital ratios and bank lending: a matched bank approach", Journal of Financial Intermediation, Vol. 22 No. 4, pp. 663-687, doi: 10.1016/j.jfi. 2013.06.003.

Demirgüç-Kunt, A., Martinez Peria, M.S. and Tressel, T. (2020), "The global financial crisis and the capital structure of firms: was the impact more severe among SMEs and non-listed firms?", Journal of Corporate Finance, Vol. 60, doi: 10.1016/j.jcorpfin.2019.101514.

de Jong, A., Kabir, R. and Nguyen, T.T. (2008), "Capital structure around the world: the roles of firmand country-specific determinants", Journal of Banking and Finance, Vol. 32 No. 9, pp. 1954-1969, doi: 10.1016/j.jbankfin.2007.12.034.

Diamond, D.W. and Rajan, R.G. (2002), "A theory of bank capital”, Journal of Finance, Vol. 55 No. 6, doi: 10.1111/0022-1082.00296.

Doku, J.N., Kpekpena, F.A. and Boateng, P.Y. (2019), "Capital structure and bank performance: empirical evidence from Ghana”, African Development Review, Vol. 31 No. 1, pp. 15-27, doi: 10. $1111 / 1467-8268.12360$.

Dowd, K. (1999), "Does asymmetric information justify bank capital adequacy regulation?", Cato Journal, Vol. 19 No. 1, pp. 39-47.

Dursun-de Neef, H.Ö. and Schandlbauer, A. (2020), COVID-19 and European Banks (Preprint), SSRN.

D'Amato, A. (2020), "Capital structure, debt maturity, and financial crisis: empirical evidence from SMEs", Small Business Economics, Vol. 55 No. 4, pp. 919-941, doi: 10.1007/s11187-019-00165-6.

Flannery, M. (1994), "Debt maturity and the deadweight cost of leverage: optimally financing banking firms", American Economic Review, Vol. 84 No. 1, pp. 320-331, doi: 10.2307/2117987.

Frank, M.Z. and Goyal, V.K. (2004), "The effect of market conditions on capital structure adjustment", Finance Research Letters, Vol. 1 No. 1, pp. 47-55, doi: 10.1016/S1544-6123(03)00005-9.

Gertler, M. and Kiyotaki, N. (2010), "Financial intermediation and credit policy in business cycle analysis", in Handbook of Monetary Economics. doi: 10.1016/B978-0-444-53238-1.00011-9.

Ghosh, S. and Chatterjee, G. (2018), "Capital structure, ownership and crisis: how different are banks?", Journal of Financial Regulation and Compliance, Vol. 26 No. 2, pp. 300-330, doi: 10.1108/JFRC-092016-0085.

Goedde-Menke, M., Langer, T. and Pfingsten, A. (2014), "Impact of the financial crisis on bank run risk - danger of the days after", Journal of Banking and Finance, Vol. 40, pp. 522-533, doi: 10.1016/j. jbankfin.2013.11.028. 
AJEB

6,2

Goodhart, C.A.E. (2008), "The regulatory response to the financial crisis", Journal of Financial Stability, Vol. 4 No. 4, pp. 351-358, doi: 10.1016/j.jfs.2008.09.005.

Gorton, G. and Winton, A. (2017), "Liquidity provision, Bank Capital, and the Macroeconomy", Journal of Money, Credit and Banking, Vol. 49 No. 1, pp. 5-37, doi: 10.1111/jmcb.12367.

Gropp, R. and Heider, F. (2010), "The determinants of bank capital structure”, Review of Finance, Vol. 14 No. 4, pp. 587-622, doi: 10.1093/rof/rfp030.

Grosse-Rueschkamp, B., Steffen, S. and Streitz, D. (2019), "A capital structure channel of monetary policy”, Journal of Financial Economics, Vol. 133 No. 2, pp. 357-378, doi: 10.1016/j.jfineco.2019. 03.006 .

Han, R. and Melecky, M. (2014), "Financial inclusion for financial stability access to bank deposits and the growth of deposits in the global financial crisis", World Development Report.

Hellmann, T.F., Murdock, K.C. and Stiglitz, J.E. (2000), "Liberalization, moral hazard in banking, and prudential regulation: are capital requirements enough?”, American Economic Review, Vol. 90, pp. 147-165, doi: 10.1257/aer.90.1.147.

Hoque, H. and Kashefi-Pour, E. (2015), "Bank level and country level determinants of bank capital structure and funding sources”, SSRN Electronic Journal. doi: 10.2139/ssrn.2648129.

Hussien, M.E., Alam, M.M., Murad, M.W. and Wahid, A. (2019), "The performance of Islamic banks during the 2008 global financial crisis Evidence from the Gulf Cooperation Council countries", Journal of Islamic Accounting and Business Research, Vol. 10 No. 3, pp. 407-420, doi: 10.1108/ JIABR-01-2017-0011.

Jackson, P., Furfine, C., Yoneyama, M. and Hancock, D. (1999), Capital Requirements and Bank Behaviour: The Impact of the Basle Accord, in BANk.

Johnson, S.A. (1998), "The effect of bank debt on optimal capital structure", Financial Management, Vol. 27 No. 1, pp. 47-56, doi: 10.2307/3666150.

Kalemli-Ozcan, S., Sorensen, B. and Yesiltas, S. (2012), "Leverage across firms, banks, and countries", Journal of International Economics, Vol. 88 No. 2, pp. 284-298, doi: 10.1016/j.jinteco.2012.03.002.

Košak, M., Li, S., Lončarski, I. and Marinč, M. (2015), "Quality of bank capital and bank lending behavior during the global financial crisis", International Review of Financial Analysis, Vol. 37, pp. 168-183, doi: 10.1016/j.irfa.2014.11.008.

Li, L., Strahan, P.E. and Zhang, S. (2020), "Banks as lenders of first resort: evidence from the COVID19 crisis", The Review of Corporate Finance Studies, Vol. 9 No. 3, pp. 472-500, doi: 10.1093/rcfs/ cfaa009.

Lipson, M.L. and Mortal, S. (2009), "Liquidity and capital structure", Journal of Financial Markets, Vol. 12 No. 4, pp. 611-644, doi: 10.1016/j.finmar.2009.04.002.

Miles, D. (1995), "Optimal regulation of deposit taking financial intermediaries”, European Economic Review, Vol. 39 No. 7, pp. 1365-1384, doi: 10.1016/0014-2921(94)00101-5.

Modigliani, F. and Miller, M.H. (1958), "The cost of capital, corporation finance and the theory of investment”, The American Economic Review, Vol. 48 No. 3, pp. 261-297.

Mohammad, K.U. and Nishiyama, S.I. (2019), "An empirical investigation into the effect of explicit deposit insurance and design on the liability structure of banks", Journal of Central Banking Theory and Practice, Vol. 8 No. 3, pp. 179-206, doi: 10.2478/jcbtp-2019-0030.

Mohammad, K.U., Affan, M. and Muhammad, K.U. (2021), "Post-crisis behavior of banks in Asia: a case of chronic over-capitalization", The Journal of Asian Finance, Economics and Business, Vol. 8 No. 3, pp. 517-525.

Orgler, Y.E. and Taggart, R.A. (1983), "Implications of corporate capital structure theory for banking institutions: note", Journal of Money, Credit and Banking, Vol. 15, pp. 212-221, doi: 10.2307/ 1992401.

Pennacchi, G.G. (1987), “A reexamination of the over- (or under-) pricing of deposit insurance”, Journal of Money, Credit and Banking, Vol. 19 No. 3, pp. 340-360, doi: 10.2307/1992081. 
Peura, S. and Keppo, J. (2006), "Optimal bank capital with costly recapitalization", The Journal of Business, Vol. 79 No. 4, pp. 2163-2201, doi: 10.1086/503660.

Qayyum, N. and Noreen, U. (2019), "Impact of capital structure on profitability: a comparative study of Islamic and conventional banks of Pakistan", Journal of Asian Finance, Economics and Business, Vol. 6 No. 4, pp. 65-74, doi: 10.13106/jafeb.2019.vol6.no4.65.

How covid affected capital structure of banks

Rajan, R.G. and Zingales, L. (1995), "What do we know about capital structure? Some evidence from international data", The Journal of Finance, Vol. 50 No. 5, pp. 1421-1460, doi: 10.1111/j.15406261.1995.tb05184.x.

Sari, N.K., Fadah, I. and Sukarno, H. (2018), "Determinan Struktur modal bank”, Ekuitas(Jurnal Ekonomi Dan Keuangan), Vol. 17 No. 1, doi: 10.24034/j25485024.y2013.v17.i1.265.

Schepens, G. (2016), "Taxes and bank capital structure”, Journal of Financial Economics, Vol. 120 No. 3, pp. 585-600, doi: 10.1016/j.jfineco.2016.01.015.

Schularick, M., Steffen, S. and Tröger, T. (2020), Bank capital and the European recovery from the COVID-19 crisis, Discussion Paper No. 14927, Centre for Economic Policy Research.

Sharpe, I.G. (1995), "Determinants of capital structure of Australian trading banks", Asia Pacific Journal of Management, Vol. 12, pp. 97-121, doi: 10.1007/BF01734388.

Sundaresan, S.M. and Wang, Z. (2014), "Bank liability structure”, SSRN Electronic Journal. doi: 10. 2139/ssrn.2495579.

Tran, D.V., Hassan, M.K., Paltrinieri, A. and Nguyen, T.D. (2020), "The determinants of bank capital structure in the world", The Singapore Economic Review, Vol. 65 No. 6, pp. 1457-1489, doi: 10. 1142/s0217590820500010. 

AJEB
Annexure

268

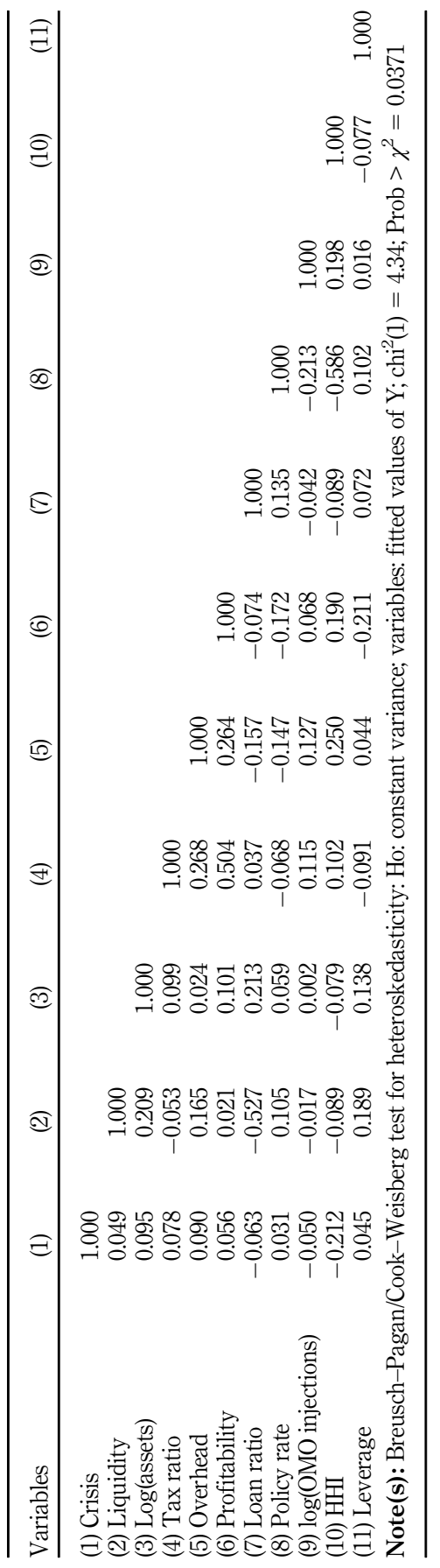

Table A1.

Matrix of correlations

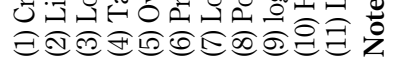




\begin{tabular}{|c|c|c|c|}
\hline & VIF & $1 / \mathrm{VIF}$ & How covid \\
\hline Liquidity & 1.757 & 0.569 & structure of \\
\hline Loan ratio & 1.751 & 0.571 & \\
\hline $\mathrm{HHI}$ & 1.74 & 0.575 & Dank \\
\hline Policy rate & 1.628 & 0.614 & \\
\hline Profitability & 1.429 & 0.7 & \\
\hline Tax ratio & 1.42 & 0.704 & 269 \\
\hline $\log A$ & 1.279 & 0.782 & \\
\hline Overhead & 1.234 & 0.81 & \\
\hline crisis & 1.11 & 0.901 & Table A2. \\
\hline Log(OMO Inj) & 1.075 & 0.931 & Variance inflation \\
\hline Mean VIF & 1.442 & & \\
\hline
\end{tabular}

\begin{tabular}{llll}
\hline Variable & Formula & Source \\
\hline Leverage & 1-(Capital/Total sssets) & Balance sheet/Datastream \\
Profitability & EBIT/Total assets & Balance sheet/Datastream \\
Log(total assets) & Log of total assets & Balance sheet/Datastream \\
Liquidity ratio & Current assets/Total assets & Balance sheet/Datastream \\
Tax ratio & Tax/Total assets & Balance sheet/Datastream & \\
Loan ratio & Total loans/Total assets & Balance sheet/Datastream & \\
Overhead & Noninterest expenses/Total assets & Balance sheet/Datastream & \\
Industry leverage & Average of leverage per period & & \\
OMO injections & Log of sum of all injections & State Bank of Pakistan data & Table A3. \\
Policy rate & - & State Bank of Pakistan data & List of formulas \\
\hline
\end{tabular}

\section{Corresponding author}

Khalil Ullah Mohammad can be contacted at: khalilullah.buic@bahria.edu.pk

For instructions on how to order reprints of this article, please visit our website:

www.emeraldgrouppublishing.com/licensing/reprints.htm

Or contact us for further details: permissions@emeraldinsight.com 